the same wood when distilled with steam in an ordinary essential-oil still yielded an oil having an optical rotation of $-\mathrm{I} 4^{\circ}$ or less. It was also noted that the oil obtained by the assay method was readily soluble in 5 volumes of 70 per cent alcohol at $25^{\circ} \mathrm{C}$., whereas the oil obtained by the ordinary steam distillation required more than 5 volumes of 70 per cent alcohol to dissolve it. Thus a sandalwood which was known to contain an oil which would meet the U. S. P. requirements, would yield by ordinary steam distillation an oil which would no longer meet these requirements. There must, therefore, be some decided change in the oil during distillation with steam.

To study this condition, 500 lbs. of sandalwood were distilled with steam and samples of each day's run collected and the physical properties determined. The results were as follows:

\begin{tabular}{|c|c|c|c|c|}
\hline Day & Sp. Gr. & Ref. Ind. & Opt. Rot. & $\begin{array}{l}\text { Solubility at } 25^{\circ} \mathrm{C} \text {. } \\
\text { in } 5 \text { parts } 70 \% \text { alcohol }\end{array}$ \\
\hline $\begin{array}{l}1 \text { st } \\
2 \mathrm{nd}\end{array}$ & $\begin{array}{l}0.969 \\
0.970\end{array}$ & $\begin{array}{l}1.5017 \\
1.5020\end{array}$ & $\begin{array}{l}-12^{\circ} 34^{\prime} \\
-12^{\circ} 22^{\prime}\end{array}$ & $\begin{array}{l}\text { O. } \mathrm{K} \text {. at } 40^{\circ} \text { to } 50^{\circ} \mathrm{C} \text {. } \\
\text { O. } \mathbf{K} \text {, at } 25^{\circ} \mathrm{C} .\end{array}$ \\
\hline $3 \mathrm{rd}$ & 0.972 & 1.5027 & $-12 \circ 46^{\prime}$ & $\mathrm{O} . \mathrm{K}$ at $25^{\circ} \mathrm{C}$ \\
\hline $4 \mathrm{th}$ & 0.974 & 1.5030 & $-12^{\circ} 54^{\prime}$ & o. $\mathbf{K}$ at $25^{\circ} \mathrm{C}$. \\
\hline 5 th & 0.976 & 1.5035 & $-130.10^{\prime}$ & $0 . \mathrm{K}$, at $25^{\circ} \mathrm{C}$ \\
\hline 6 th & 0.978 & 1.5037 & $-12^{\circ} 30^{\prime}$ & $\mathrm{O}$. $\mathrm{K}$ at $25^{\circ} \mathrm{C}$ \\
\hline $7 \mathrm{th}$ & 0.978 & 1.5045 & $-11 \circ 8^{\prime}$ & $\mathrm{O} . \mathrm{K}$ at $25^{\circ} \mathrm{C}$ \\
\hline $8 \mathrm{th}$ & 0.9795 & 1.5046 & $-10^{\circ} 4^{\prime}$ & $\mathrm{O} . \mathrm{K}$ at $26.5^{\circ} \mathrm{C}$. \\
\hline $9 \mathrm{th}$ & 0.981 & 1.5046 & $-9^{\circ} 10^{\prime}$ & $\mathrm{O}$. K at $29^{\circ} \mathrm{C}$. \\
\hline $10 \mathrm{th}$ & 0.9815 & 1.5046 & $-8^{\circ} 20^{\prime}$ & 0 . K. at $32^{\circ} \mathrm{C}$. \\
\hline $11 \mathrm{th}$ & 0.9820 & 1.5045 & $-7^{\circ} 45^{\prime}$ & $0 . \mathrm{K}$ at $35^{\circ} \mathrm{C}$. \\
\hline $12 \mathrm{th}$ & 0.983 & 1.5045 & $-7^{\circ} 8^{\prime}$ & O. K. at $38^{\circ} \mathrm{C}$. \\
\hline & 0.982 & 1.5046 & $-6^{\circ} 34^{\prime}$ & $\mathrm{O} . \mathrm{K}$ at $44^{\circ} \mathrm{C}$ \\
\hline
\end{tabular}

It will be noted that there was a gradual increase in specific gravity with each day's run from 0.969 to 0.982 . Also that the refractive index steadily increased from I.50I 7 to 1.5046 . The optical rotation was fairly constant for 5 days at - I $2^{\circ}$ to $-\mathrm{I} 3^{\circ}$ and then steadily decreased to $-6^{\circ} 34^{\prime}$. With the exception of the first day's run, the oil was soluble in 5 parts of 70 per cent alcohol at $25^{\circ} \mathrm{C}$. for the first 7 days, but the eighth day's run was no longer soluble at $25^{\circ} \mathrm{C}$, and the solubility grew gradually less up to the end of the distillation.

To determine if this change in the optical rotation of santal oil during distillation was due to prolonged exposure of the oil to boiling water, a sample of oil having an optical rotation of $-20^{\circ} 40^{\prime}$ was boiled continuously for several weeks in a glass flask with a reflux condenser. The same experiment was also carried out by boiling with a so per cent solution of sodium chloride.

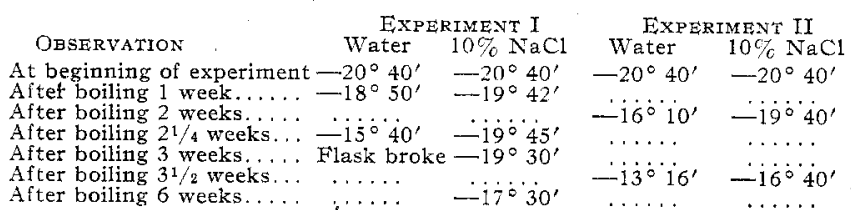

It will be noted that there was a very decided change in the optical rotation of the santal oil by boiling with water, the rotation decreasing from $-20^{\circ} 40^{\prime}$ to $-13^{\circ}$ ${ }_{1} 6^{\prime}$ in $3^{1 / 2}$ weeks. The change by boiling with the Io per cent salt solution was much less, being reduced to - $6^{\circ} 40^{\prime}$ in the same length of time.

We must conclude then that under certain conditions prolonged contact with boiling water brings about decided changes in the composition of santal oil and greatly reduces the optical rotation. These same changes take place in the oil to a greater or less extent during the distillation of the oil from the wood with steam and probably accounts for much of the santal oil on the market having a low optical rotation and poor solubility.

The writer wishes to express his thanks to $\mathrm{Mr}$. S. T. McCallum for his assistance during this work. Chemical, Laboratory, Parke, Davis \& Company DETROIT, MICHIGAN

\section{NOTE ON AMERICAN CHARLOCK OIL}

By H. S. BaIley AND I. B. BuRnetT Received December 21, 1915

During the course of an investigation into the "Production, Botanical Composition and Volatile Oil Strength of American Wild Mustard Seed," Winton and Bornmann ${ }^{1}$ separated from northwestern wheat screenings several samples of fairly pure charlock (Brassica arvensis) seed. These we combined and further purified in the laboratory until our material was 98-99 per cent charlock, the remainder being nearly all brown mustard (Brassica juncea).

After taking out a sample for analysis, the seed was ground in a drug mill and pressed cold in a small hydraulic press, the material remaining under pressure over night. The press cake was then reground and divided into two portions, one of which was extracted with petroleum ether (b. p. $35-60^{\circ}$ ) and the other with ethyl ether in a Soxhlet apparatus.

The original seed contained 4.I per cent moisture, as determined in an atmosphere of $\mathrm{CO}_{2}$ at $100^{\circ} \mathrm{C}$., 30.0 per cent ether extract and 29.6 per cent petroleum ether extract. The chemical and physical factors of the expressed and extracted oils together with an analysis by Grimme of oil of charlock, probably the ether extract of Sinapis arvensis, are given in the accompanying table.

\begin{tabular}{|c|c|c|c|c|}
\hline Physical and $\mathrm{CH}$ & $\begin{array}{l}\text { EMICAL, FAC } \\
\text { Expressed } \\
\text { Oil }\end{array}$ & $\begin{array}{c}\text { Ether } \\
\text { Extract }\end{array}$ & $\begin{array}{l}\text { ChaRLock } \\
\text { Petroleum } \\
\text { Ether } \\
\text { Extract }\end{array}$ & $\begin{array}{c}\text { Grimme's } \\
\text { Analysis }\end{array}$ \\
\hline $\begin{array}{l}\text { Specific Gravity, } 15 / 15 \ldots \ldots \\
\text { Refractive Index, } 25^{\circ} \ldots \ldots \ldots \\
\text { Saponification No.......... } \\
\text { Iodine No., Hanus... }\end{array}$ & $\begin{array}{l}0.9221 \\
1.4734 \\
182.9 \\
121.1\end{array}$ & $\begin{aligned} 0.9272 \\
1.4739 \\
183.1 \\
119.8\end{aligned}$ & $\begin{aligned} 0.9212 \\
1.4729 \\
181.0 \\
119.3\end{aligned}$ & $\begin{aligned} & 0.9228 \\
& 1.4720(a) \\
& 179.4 \\
& 102.6(b)\end{aligned}$ \\
\hline $\begin{array}{l}\text { saponifiable........ } \\
\text { Soluble Acids... } \\
\text { Mean Mol. Wt. of Ins. Acids }\end{array}$ & $\begin{array}{r}95.3 \\
0.0 \\
339.1\end{array}$ & $\begin{array}{r}95.4 \\
0.0 \\
338.1\end{array}$ & $\begin{array}{r}95.2 \\
0.0 \\
334.8\end{array}$ & $\begin{array}{r}94.21 \\
312.4\end{array}$ \\
\hline $\begin{array}{l}\text { Liguto AcIDs: } \\
\text { Pet cent } \ldots \ldots \ldots \ldots \ldots \ldots \\
\text { Iodine No.......... }\end{array}$ & $\begin{array}{r}89.3 \\
126.0\end{array}$ & $\begin{array}{r}90.0 \\
122.3\end{array}$ & $\begin{array}{r}90.0 \\
125.0\end{array}$ & $\cdots$ \\
\hline $\begin{array}{l}\text { Soltd Acros: } \\
\text { Per cent } \ldots \ldots \ldots \ldots \ldots \ldots \\
\text { Iodine No......... }\end{array}$ & $\begin{array}{l}3.1 \\
\ldots\end{array}$ & $\begin{array}{r}1.6 \\
62.0\end{array}$ & $\begin{array}{r}2.0 \\
61.0\end{array}$ & $\ldots$ \\
\hline
\end{tabular}

(a) Calculated to $25^{\circ}$ from Grimme's value 1.4738 at $20^{\circ}$

As has been pointed out by Winton and Bornmann, there are large quantities of so-called "Wild Mustard" which contain varying proportions of charlock and brown mustard separated from American grains. Some of this is already being utilized as an oil material. Whether or not this oil can be sufficiently refined to make it suitable for food purposes remains to be seen, but undoubtedly it can be used in soap making and possibly in cheap paints.

Bureau of Chemistry, WAshington

1 Tuis Journal, 7 (1915), 684.

2 Lewkowitsch's "Chem. Tech. and Anal of Oils, Fats and Waxes," 5th Ed., Vol. II, p. 271. 